\title{
THE COMPARISON OF PHOTOSYNTHESIS PARAMEATERS OF DIFFERENT WHEAT (TRITICUM AESTIVUM L.) VARIETIES
}

Ilona VAGUSEVIČIENĖ, Department of Agroecosystems and Soil Sciences, Faculty of Agronomy, Vytautas Magnus University. K. Donelaičio g. 58, 44248 Kaunas, Lithuania, ilona.vaguseviciene@ vdu.lt

Sonata KAZLAUSKAITÉ, Department of Agroecosystems and Soil Sciences, Faculty of Agronomy, Vytautas Magnus University. K. Donelaičio g. 58, 44248 Kaunas, Lithuania, sonata.kazlauskaite@ vdu.lt (corresponding author)

Irena PRANCKIETIENE், Department of Agroecosystems and Soil Sciences, Faculty of Agronomy, Vytautas Magnus University. K. Donelaičio g. 58, 44248 Kaunas, Lithuania, irena.pranckietiene@ vdu.lt

Gintarė SUJETOVIENĖ, Department of Environmental Sciences, Faculty of Natural Sciences, Vytautas Magnus University, K. Donelaičio g. 58, 44248 Kaunas, Lithuania gintare.sujetoviene@ vdu.1t

Arvydas KANAPICKAS, Department of Environmental Sciences, Faculty of Natural Sciences, Vytautas Magnus University, K. Donelaičio g. 58, 44248 Kaunas, Lithuania arvydas.kanapickas@ vdu.lt

Audronė ŽEBRAUSKIENĖ, Department of Agrobiology and Food Sciences, Faculty of Agronomy, Vytautas Magnus University. K. Donelaičio g. 58, 44248 Kaunas, Lithuania, audrone.zebrauskiene@ vdu.lt

Field experiments were carried out at the Experimental Station of Vytautas Magnus University Agriculture Academy in Lithuania (54 ${ }^{\circ}$ 53' 3.26", 2350' 33.25") during 2017-2018. Six winter wheat varieties were studied in the experiment: 'Skagen' (control), 'Julius', 'Edvins', 'Artist', 'Aron' and 'Evina', which were sown on September 15. Preceding crop - winter rape. Seed rate - 4.5 million ha $^{-1}$. The aspects of the dynamics of photosynthesis pigments in winter wheat leaves depending on variety is analysed in the article. Physiological activity of the plant, the growth and development are the most important moments decisive the accumulation of these pigments in the plant. Thus, the general condition of the plant might be described by the composition and content of photosynthesis pigments chlorophyll $a, b$ and carotenoids. Spectrophotometric Wettstein method and "Genesys" 6 spectrophotometer were used for determination of the content of photosynthesis pigments (chlorophyll $a, b$ and carotenoids) in green leaf mass in $96 \%$ ethyl alcohol extract.

The accumulated amounts of photosynthetic pigments (chlorophylls $a, b$ and carotenoids) in different varieties of winter wheat leaves differed. Winter wheat variety 'Aron' accumulated the highest contents of photosynthetic pigments during the tillering and stem elongation stages, meanwhile during the heading - anthesis and early milky maturity stages winter wheat varieties 'Artist' and 'Skagen' demonstrated the best results. The LAI of different varieties of winter wheat differed in the field experiment. Significantly higher LAI was defined for winter wheat variety Artist (0.9) after the resumption of vegetation (BBCH 24-27) and for 'Skagen' (4.0) at the end of vegetation (BBCH 70-73). The highest LAI of winter wheat is determined during the heading - anthesis stage (varieties 'Aron', 'Edvins', 'Skagen'). During the growing season, the lowest LAI was observed for winter wheat variety 'Evina'.

Keywords: Winter wheat, varieties, photosynthesis pigments, leaf area index.

\section{INTRODUCTION}

Plant photosynthesis parameters are increasingly used to assess the effects of different varieties and various agrotechnical measures, stress factors on agricultural crops. Monitoring of photosynthesis parameters of crops during vegetation allows to react in time to the tendencies of formation of productivity elements and to adjust the applied technological measures. Observations of chlorophyll $a, b$ content, chlorophyll $a / b$ ratio, leaf area index provide the most information about crop condition.

The processes such as formation, translocation, partitioning and accumulation of assimilates during grain filling period largely influence yields of wheat grain. Furthermore, the photosynthetic activity of the leaves and the ability to store the nutrients after the anthesis are recognized as the main wheat grain yield limiting factors (Bijanzadeh and Emam, 2010).

In order to produce a productive winter wheat crop, it is necessary to apply appropriate cultivation technology and the select varieties that are tolerant to the changing climate (Abdoli et al., 2013). Chlorophylls $a$ and $b$ and carotenoids are the most important in the process of photosynthesis. Chlorophyll is an important light-absorbing photosynthetic pigment, which mainly determines the photosynthetic capacity of a plant and, consequently, its growth and development (Croft et al., 2017). The amount of photosynthetic pigments in the leaves varies depending on the plant species, variety and environmental conditions (Daughtry et al., 2000). It was found that the unequal change in photosynthetic parameters

Copyright (๑) 2021 The Authors. Published by Vytautas Magnus University. This is an open-access article distributed under the terms of the Creative Commons Attribution License (CC BY 4.0), which permits unrestricted use, distribution, and reproduction in any medium, provided the original author and source are credited. 
of different winter wheat varieties was evident in the presence of drought and depended on plant development (Janušauskaite et al., 2013; Sharifi and Mohammadkhani, 2016; Wang et al., 2018). In the spring barley crops, the highest photosynthetic productivity was defined in the stages of heading-anthesis - milk maturity, that is, during intensive growth - accumulation of dry matter mass. Due to the increasing leaf area, more intense retained solar radiation was determined during the formation of a denser spring barley crop (Pilipavičius et al., 2011). The leaf area index (LAI) shows how much the leaf area of a plant covers a certain area of the soil surface. Determining this index reveals the ability of plants to absorb sunlight energy, which is important for growth, development, and productivity formation.

The aim of this study was to compare the content of photosynthetic pigments and leaf area index (LAI) in the leaves of different winter wheat varieties during vegetation.

\section{MATERIALS AND METHODS}

Field place and conditions. Field experiments were carried out at the Experimental Station of Vytautas Magnus University Agriculture Academy in Lithuania (54 53' 3.26", 23 50' 33.25") during 2017-2018. The soil of the experimental field is Cal(ca)ri-Epihypogleyic Luvisol (WRB, 2014). Soil tests were performed before the experiment: the $\mathrm{pH}_{\mathrm{KCl}}$ of the topsoil was 7.0, the concentration of available $\mathrm{P}_{2} \mathrm{O}_{5}-392 \mathrm{mg} \mathrm{kg}^{-1}$, available $\mathrm{K}_{2} \mathrm{O}-163 \mathrm{mg} \mathrm{kg}^{-1}$, and the humus content in the surface layer of soil was $2.72 \%$.

During the experiment, six winter wheat varieties were studied: 'Skagen' (control), 'Julius', 'Edvins', 'Artist', 'Aron' and 'Evina', which were sown on 15 September using the sowing-machine ACCORD "m-drill". Winter rape was grown before the crop. Seed rate -4.5 million $\mathrm{ha}^{-1}$.

Experimental design. Background fertilization of winter wheat: ammonium nitrate (N68+N68) was applied in the spring after the regrowth of winter wheat $(\mathrm{BBCH} 24-26)$ and at the end of winter wheat tillering stage (BBCH 28-30). Winter wheat was additionally fertilized through the leaves with urea (N10) during the stem elongation stage (BBCH 3235). Plant protection measures were applied to prevent suppression of plant growth due to outbreaks of weeds, pests and diseases.

Experimental and analytical methods. Soil $\mathrm{pH}_{\mathrm{KCl}}$ was measured by extraction with $1 \mathrm{~N} \mathrm{KCl}$ using potentiometric method, organic carbon $(\mathrm{C})$ - by the Tyurin method, available phosphorus $\left(\mathrm{P}_{2} \mathrm{O}_{5}\right)$ and potassium $\left(\mathrm{K}_{2} \mathrm{O}\right)$ were determined according the Egner-Riehm-Domingo (A-L) method. Mineral nitrogen (Nmin) was determined by extraction with $1 \mathrm{~N}$ $\mathrm{KCl}$ and total nitrogen was measured by the Kjeldahl method.

Analysis of photosynthetic pigment content was performed in growth stages of BBCH 24-27, 32-34, 58-62, and 70-73. Randomly, from each site of different varieties winter wheat 5 plants were pulled up, which were used for plant growth and developmental stage determination, photosynthetic pigments (chlorophylls $\mathrm{a}, \mathrm{b}$ and carotenoids) investigation and leaf assimilation area measurement. The content of photosynthetic pigments in the fresh leaf mass was determined using 96\% ethyl alcohol according to the Wettstein spectrophotometry method. A Genesys 6 spectrophotometer was used in the corresponding wave spectrum: $440.5 \mathrm{~nm}$ for carotenoids; $662 \mathrm{~nm}$ for chlorophyll $a$; $644 \mathrm{~nm}$ for chlorophyll $b$ (von Wettstein, 1957). The content of pigments was determined according to the following equations:

$$
\begin{aligned}
\text { Chl } a= & 9,784 \times D_{662}-0,990 \times D_{664}(C \times V) /(P \times 1000) ; \\
\text { Chl } b= & 21,426 \times D_{644}-4,650 \times D_{662}(C \times V) /(P \times 1000) ; \\
& \text { Carotenoid }=4,695 \times D_{440,5}-0,268(C h l a+b)(C \times V) /(P \times 1000) ;
\end{aligned}
$$

where $\mathrm{C}$ - pigment content ( $\left.\mathrm{mg} \mathrm{g}^{-1}\right) ; \mathrm{V}$ - extracts volume $(\mathrm{ml}) ; \mathrm{P}$ - fresh mass of plants $(\mathrm{g})$.

Winter wheat leaf assimilation area was measured using a WinDIAS leaf area meter (Delta-T Devices).

Statistical analysis. Statistical analysis of the experimental data was performed by analysis of variance (ANOVA) using SELEKCIJA software package. The significance of the data was determined according to the Fisher's criterion with significance levels of $\mathrm{P} \leq 0.01$ and 0.05 .

\section{RESULTS AND DISCUSSION}

Chlorophyll content is one of the indicators of photosynthetic activity. The productivity of photosynthesis was found to depend on the cultivated variety, mineral nutrition, and environmental conditions (Bojovic and Stojanovic, 2005; Kovačević et al., 2017; Niroula et al., 2019; Rezaei et al., 2018; Skudra and Ruza, 2017; Vuletić and Španić, 2020). Additional fertilization with nitrogen fertilizers inhibits the degradation of photosynthetic pigments, prolongs the period of active photosynthesis and ensures more efficient transport of assimilates to the seeds, resulting in a yield. After the regrowth of winter wheat, the leaves have lower content of photosynthetic pigments during the tillering and stem elongation stages. Winter wheat accumulates the highest content of photosynthetic pigments at the end of the anthesis at the beginning of grain formation stages (Skudra and Ruza, 2017; Tian et al., 2014).

In the spring, when vegetation regrowth, the lowest content of chlorophyll $a$ was found in the leaves of the control winter wheat variety 'Skagen' $\left(0.93 \mathrm{mg} \mathrm{g}^{-1}\right)$ and the significantly higher content of chlorophyll $a$ was found in the leaves of the variety 'Aron' (1.30 $\left.\mathrm{mg} \mathrm{g}^{-1}\right)$. The content of chlorophyll $a$ in the leaves of other winter wheat varieties did not differ significantly and ranged from 1.03 to $1.21 \mathrm{mg} \mathrm{g}^{-1}$ (Table 1). The lower content of chlorophyll $a$ in the leaves of 'Skagen' 
variety may have been influenced by the fact that the plants of this variety start spring vegetation slower than the wheat of other varieties studied.

At the stem elongation stage (BBCH 32-34), higher content of chlorophyll $a$ was determined in the leaves of all winter wheat varieties, but in the Skagen leaves, the content of chlorophyll $a$ remained significantly lower $\left(1.02 \mathrm{mg} \mathrm{g}^{-1}\right)$. The highest content of chlorophyll $a\left(1.79-2.67 \mathrm{mg} \mathrm{g}^{-1}\right)$ in winter wheat leaves was determined at the beginning of the early milk maturity stage. At this growth stage, the highest chlorophyll $a$ content was in the leaves of 'Artist' $\left(2.67 \mathrm{mg} \mathrm{g}^{-1}\right)$, 'Skagen' (2.56 mg g-1), and 'Julius' (2.43 $\left.\mathrm{mg} \mathrm{g}^{-1}\right)$. Significantly lower content of chlorophyll $a$ was found in the leaves of the shorter vegetation variety 'Edvins' (1.79 $\left.\mathrm{mg} \mathrm{g}^{-1}\right)$.

Table 1. Chlorophyll $a$ content $\left(\mathrm{mg} \mathrm{g}^{-1}\right)$ in the leaves of different winter wheat varieties at the different growth stages

\begin{tabular}{|l|c|c|c|c|}
\hline \multirow{2}{*}{ Cultivar } & \multicolumn{4}{c|}{ Growth stage } \\
\cline { 2 - 5 } & $\begin{array}{c}\text { BBCH 24-27 } \\
\text { (Tillering) }\end{array}$ & $\begin{array}{c}\text { BBCH 32-34 } \\
\text { (Stem elongation) }\end{array}$ & $\begin{array}{c}\text { BBCH 58-62 } \\
\text { (Heading-anthesis) }\end{array}$ & $\begin{array}{c}\text { BBCH 70-73 } \\
\text { (Early milk maturity) }\end{array}$ \\
\hline 'Skagen' & $0.93 \mathrm{~b}$ & $1.02 \mathrm{c}$ & $1.76 \mathrm{~b}$ & 2.56 \\
\hline 'Julius' & $1.18 \mathrm{ab}$ & $1.79 \mathrm{a}$ & $2.23 \mathrm{a}$ & 2.43 \\
\hline 'Edvins' & $1.21 \mathrm{ab}$ & $1.34 \mathrm{~b}$ & $1.81 \mathrm{~b}$ & 1.79 \\
\hline 'Artist' & $1.13 \mathrm{ab}$ & $1.72 \mathrm{a}$ & $2.26 \mathrm{a}$ & 2.67 \\
\hline 'Aron' & $1.30 \mathrm{a}$ & $1.78 \mathrm{a}$ & $2.10 \mathrm{a}$ & 2.35 \\
\hline 'Evina' & $1.18 \mathrm{ab}$ & $1.66 \mathrm{ab}$ & $2.18 \mathrm{a}$ & 2.48 \\
\hline
\end{tabular}

Note. Different letters within a column indicate significantly different means at the $95 \%$ confidence level

The lowest content of chlorophyll $b$ in the leaves of different winter wheat varieties was found during the tillering stage $\left(0.25-0.38 \mathrm{mg} \mathrm{g}^{-1}\right)$, and the content of this pigment increased at the beginning of grain formation (Table 2). Significantly higher content of chlorophyll $b$ was determined in the leaves of 'Artist' $\left(0.86 \mathrm{mg} \mathrm{g}^{-1}\right)$ and the lowest - in the leaves of 'Edvins' (0.59 $\left.\mathrm{mg} \mathrm{g}^{-1}\right)$.

Table 2. Chlorophyll $b$ content (mg g-1) in the leaves of different winter wheat varieties at the different growth stages

\begin{tabular}{|l|c|c|c|c|}
\hline \multirow{2}{*}{ Cultivar } & \multicolumn{4}{c|}{ Growth stage } \\
\cline { 2 - 5 } & $\begin{array}{c}\text { BBCH 24-27 } \\
\text { (Tillering) }\end{array}$ & $\begin{array}{c}\text { BBCH 32-34 } \\
\text { (Stem elongation) }\end{array}$ & $\begin{array}{c}\text { BBCH 58-62 } \\
\text { (Heading-anthesis) }\end{array}$ & $\begin{array}{c}\text { BBCH 70-73 } \\
\text { (Early milk maturity) }\end{array}$ \\
\hline 'Skagen' & $0.25 \mathrm{~b}$ & $0.32 \mathrm{c}$ & $0.51 \mathrm{~b}$ & $0.79 \mathrm{~b}$ \\
\hline 'Julius' & $0.33 \mathrm{a}$ & $0.54 \mathrm{a}$ & $0.64 \mathrm{a}$ & $0.76 \mathrm{bc}$ \\
\hline 'Edvins' & $0.33 \mathrm{a}$ & $0.46 \mathrm{~b}$ & $0.54 \mathrm{~b}$ & $0.59 \mathrm{~d}$ \\
\hline 'Artist' & $0.34 \mathrm{a}$ & $0.56 \mathrm{a}$ & $0.65 \mathrm{a}$ & $0.86 \mathrm{a}$ \\
\hline 'Aron' & $0.38 \mathrm{a}$ & $0.57 \mathrm{a}$ & $0.63 \mathrm{a}$ & $0.74 \mathrm{c}$ \\
\hline 'Evina' & $0.32 \mathrm{ab}$ & $0.49 \mathrm{~b}$ & $0.66 \mathrm{a}$ & $0.78 \mathrm{~b}$ \\
\hline
\end{tabular}

Note. Different letters within a column indicate significantly different means at the $95 \%$ confidence level

Carotenoids play a very important role in photosynthesis. Carotenoid biosynthesis in plants is a genetic characteristic, but environmental conditions also play an essential role. Significantly lower carotenoid content $(0.44 \mathrm{mg}$ $\mathrm{g}^{-1}$ ) was found in the winter wheat leaves of the variety 'Skagen' after regrowth during the tillering stage (Table 3). During that period, the carotenoid contents in the leaves of other winter wheat varieties studied were similar. The highest carotenoids content was in winter wheat at the stages of anthesis and milk maturity. The carotenoid content of winter wheat of the variety 'Edvins' was significantly lower $\left(0.77 \mathrm{mg} \mathrm{g}^{-1}\right)$.

Table 3. Carotenoid content $\left(\mathrm{mg} \mathrm{g}^{-1}\right)$ in the leaves of different winter wheat varieties at the different growth stages

\begin{tabular}{|l|c|c|c|c|}
\hline \multirow{2}{*}{ Cultivar } & \multicolumn{4}{c|}{ Growth stage } \\
\cline { 2 - 5 } & $\begin{array}{c}\text { BBCH 24-27 } \\
\text { (Tillering) }\end{array}$ & $\begin{array}{c}\text { BBCH 32-34 } \\
\text { (Stem elongation) }\end{array}$ & $\begin{array}{c}\text { BBCH 58-62 } \\
\text { (Heading-anthesis) }\end{array}$ & $\begin{array}{c}\text { BBCH 70-73 } \\
\text { (Early milk maturity) }\end{array}$ \\
\hline 'Skagen' & $0.44 \mathrm{~b}$ & $0.49 \mathrm{~d}$ & $0.80 \mathrm{~b}$ & $0.89 \mathrm{ab}$ \\
\hline 'Julius' & $0.65 \mathrm{a}$ & $0.78 \mathrm{a}$ & $0.87 \mathrm{a}$ & $0.87 \mathrm{~b}$ \\
\hline 'Edvins' & $0.68 \mathrm{a}$ & $0.61 \mathrm{c}$ & $0.77 \mathrm{~b}$ & $0.77 \mathrm{c}$ \\
\hline 'Artist' & $0.62 \mathrm{a}$ & $0.74 \mathrm{ab}$ & $0.90 \mathrm{a}$ & $0.88 \mathrm{ab}$ \\
\hline 'Aron' & $0.72 \mathrm{a}$ & $0.77 \mathrm{ab}$ & $0.87 \mathrm{a}$ & $0.90 \mathrm{a}$ \\
\hline 'Evina' & $0.67 \mathrm{a}$ & $0.73 \mathrm{~b}$ & $0.86 \mathrm{a}$ & $0.88 \mathrm{ab}$ \\
\hline
\end{tabular}

Note. Different letters within a column indicate significantly different means at the $95 \%$ confidence level

According to most of researchers, the ratio of chlorophylls $a$ to $b$ is 3:1. These values vary depending on the growth and development of the plants, plant species and many environmental factors (Lenaerts et al., 2019).

The chlorophyll $a / b$ ratio (3.32-3.72) in winter wheat leaves of different varieties did not differ significantly during the tillering stage (Table 4). At the stem elongation stage, winter wheat variety 'Evina' had the highest chlorophyll $a / b$ ratio (3.39), while winter wheat variety 'Edvins' showed the lowest chlorophyll $a / b$ ratio (2.91). The highest chlorophyll $a / b$ ratio was found at the anthesis stage: it ranged from 3.45 to 3.48 in S'kagen', 'Julius' and 'Artist' varieties, while chlorophyll $a / b$ ratio was significantly lower (from 3.30 to 3.35) in varieties 'Evina', 'Aron' and 'Edvins'. At the beginning 
of milk stage, the chlorophyll content in the leaves and simultaneously the $a / b$ ratio of chlorophyll changed at the same time. Significantly lower chlorophyll $a / b$ ratio was found in the leaves of 'Edvins' (3.03), and 'Artist' (3.10) compared to the leaves of other studied varieties.

Table 4. Chlorophyll $a / b$ ratio in the leaves of different winter wheat varieties at the different growth stages

\begin{tabular}{|l|c|c|c|c|}
\hline \multirow{2}{*}{ Cultivar } & \multicolumn{4}{c|}{ Growth stage } \\
\cline { 2 - 5 } & $\begin{array}{c}\text { BBCH 24-27 } \\
\text { (Tillering) }\end{array}$ & $\begin{array}{c}\text { BBCH 32-34 } \\
\text { (Stem elongation) }\end{array}$ & $\begin{array}{c}\text { BBCH 58-62 } \\
\text { (Heading-anthesis) }\end{array}$ & $\begin{array}{c}\text { BBCH 70-73 } \\
\text { (Early milk maturity) }\end{array}$ \\
\hline 'Skagen' & $3.72 \mathrm{a}$ & $3.19 \mathrm{abc}$ & $3.45 \mathrm{a}$ & $3.24 \mathrm{a}$ \\
\hline 'Julius' & $3.58 \mathrm{a}$ & $3.31 \mathrm{ab}$ & $3.48 \mathrm{a}$ & $3.20 \mathrm{a}$ \\
\hline 'Edvins' & $3.67 \mathrm{a}$ & $2.91 \mathrm{c}$ & $3.35 \mathrm{~b}$ & $3.03 \mathrm{~b}$ \\
\hline 'Artist' & $3.32 \mathrm{a}$ & $3.07 \mathrm{bc}$ & $3.48 \mathrm{a}$ & $3.10 \mathrm{~b}$ \\
\hline 'Aron' & $3.42 \mathrm{a}$ & $3.12 \mathrm{abc}$ & $3.33 \mathrm{~b}$ & $3.18 \mathrm{a}$ \\
\hline 'Evina' & $3.69 \mathrm{a}$ & $3.39 \mathrm{a}$ & $3.30 \mathrm{~b}$ & $3.18 \mathrm{a}$ \\
\hline
\end{tabular}

Note. Different letters within a column indicate significantly different means at the $95 \%$ confidence level

LAI is the ratio of the total leaf area of a crop to the total area of ground on which it stands (Sugár et al., 2017). LAI depends on environmental conditions (especially on humidity and temperature), mineral nutrition (nitrogen content), application of plant protection products, crop density and wheat genotype (Bavec et al., 2007). LAI is often used as an important index to reflect crop growth status, water regime and fertilizer management, monitoring growth conditions and predicting yield (Li et al., 2017).

During the tillering stage, LAI ranged from 0.4 to 0.9 (Table 5). Significantly the highest (0.9) LAI was found for the leaves of the 'Artist' variety and the lowest (0.4) for the leaves of the 'Evina' variety. Compared to the control variety Skagen, a significantly higher LAI was determined for 'Julius', 'Edvins' and 'Artist'. The highest LAI of the studied varieties was found at the end of the heading - anthesis stage. It was observed to be the highest during the whole vegetation period and ranged from 3.2 to 5.9. The highest LAI was determined in 'Aron' (5.9), Edvins (5.8), 'Skagen' (5.7) varieties and significantly lower in 'Evina' variety (3.2). With the initiation of milk maturity, LAI decreased. The highest LAI (4.0) was found for the winter wheat variety 'Skagen', and significantly lowest (2.8) was found for the leaves of the variety 'Evina'.

Table 5. Leaf area index (LAI) of different winter wheat varieties at the different growth stages

\begin{tabular}{|l|c|c|c|c|}
\hline \multirow{2}{*}{ Cultivar } & \multicolumn{4}{c|}{ Growth stage } \\
\cline { 2 - 5 } & $\begin{array}{c}\text { BBCH 24-27 } \\
\text { (Tillering) }\end{array}$ & $\begin{array}{c}\text { BBCH 32-34 } \\
\text { (Stem elongation) }\end{array}$ & $\begin{array}{c}\text { BBCH 58-62 } \\
\text { (Heading-anthesis) }\end{array}$ & $\begin{array}{c}\text { BBCH 70-73 } \\
\text { (Early milk maturity) }\end{array}$ \\
\hline Skagen & $0.5 \mathrm{c}$ & $3.1 \mathrm{a}$ & $5.7 \mathrm{a}$ & $4.0 \mathrm{a}$ \\
\hline Julius & $0.7 \mathrm{~b}$ & $3.1 \mathrm{a}$ & $5.4 \mathrm{~b}$ & $3.6 \mathrm{ab}$ \\
\hline Edvins & $0.7 \mathrm{~b}$ & $2.9 \mathrm{a}$ & $5.8 \mathrm{a}$ & $3.6 \mathrm{ab}$ \\
\hline Artist & $0.9 \mathrm{a}$ & $2.5 \mathrm{~b}$ & $4.5 \mathrm{c}$ & $3.6 \mathrm{ab}$ \\
\hline Aron & $0.5 \mathrm{c}$ & $2.6 \mathrm{~b}$ & $5.9 \mathrm{a}$ & $3.1 \mathrm{bc}$ \\
\hline Evina & $0.4 \mathrm{c}$ & $1.5 \mathrm{c}$ & $3.2 \mathrm{~d}$ & $2.8 \mathrm{c}$ \\
\hline
\end{tabular}

Note. Different letters within a column indicate significantly different means at the $95 \%$ confidence level

\section{CONCLUSIONS}

1. The amounts of photosynthetic pigments (chlorophylls $a, b$ and carotenoids) in different winter wheat varieties varied. The winter wheat variety 'Aron' accumulated the highest contents of photosynthetic pigments during the tillering and stem elongation stages, while during the heading - anthesis and early milky maturity stages - winter wheat varieties 'Artist' and 'Skagen'.

2. In the field experiment, LAI of different winter wheat varieties differed. Significantly higher LAI was found for the winter wheat variety 'Artist' (0.9) after the regrowth (BBCH 24-27) and for 'Skagen' (4.0) at the end of vegetation (BBCH 70-73). The highest LAI of winter wheat was determined during the heading - anthesis stage (varieties 'Aron', 'Edvins', 'Skagen'). During the growing season, the lowest LAI was observed for winter wheat variety 'Evina'.

\section{REFERENCES}

1. Abdoli M., Saeidi M., Jalali-Honarmand S., Kazemi-Gavar Heidari, H.A. Hashemzade H. 2013. The role of current photosynthesis on grain yield formation, some agronomic characteristics and germination traits in two bread wheat cultivars under terminal drought stress condition. Journal of Agriculture and Crop Science, Vol. 5, pp.1585-1594.

2. Bavec M., Vuković K., Grobelnik S., Rozman Č., Bavec F. 2007. Leaf area index in winter wheat: response on seed rate and nitrogen application by different varieties. Journal of Central European Agriculture, Vol. 8, pp. 337-341.

3. Bijanzadeh E., Emam Y. 2010. Effect of defoliation and drought stress on yield components and chlorophyll content of wheat. Pakistan Journal of Biological Sciences, Vol. 13, pp. 699-705. https://doi.org/10.3923/pjbs.2010.699.705

4. Bojovic B., Stojanovic J. 2005. Chlorophyll and carotenoid content in wheat cultivars as a function of mineral nutrition. Archives of Biological Sciences, Vol. 57, pp. 283-290. https://doi.org/10.2298/ABS0504283B 
5. Croft H., Chen J.M., Luo X., Bartlett P., Chen B., Staebler R.M. 2017. Leaf chlorophyll content as a proxy for leaf photosynthetic capacity. Global Change Biology. Vol. 23, pp. 3513-3524. https://doi.org/10.1111/gcb.13599

6. Daughtry C.S.T., Walthall C.L., Kim M.S., De Colstoun E.B., McMurtrey J.E. 2000. Estimating Corn Leaf Chlorophyll Concentration from Leaf and Canopy Reflectance. Remote Sensing of Environment, Vol. 74, pp. $229-239$. https://doi.org/10.1016/S0034-4257(00)00113-9

7. Janušauskaite D., Auškalnienè O., Feizienè D., Feiza V. 2013. Response of common barley (Hordeum vulgare L.) physiological parameters to agricultural practices and meteorological conditions. Zemdirbyste-Agriculture, Vol. 100, pp. $127-136$. https://doi.org/10.13080/z-a.2013.100.016

8. Kovačević J., Mazur M., Drezner G., Lalić A., Sudarić A., Dvojković K., Viljevac-Vuletić M., Josipović M., Josipović A., MarkuljKulundžić A., Lepeduš H. 2017. Photosynthetic efficiency parameters as indicators of agronomic traits of winter wheat cultivars in different soil water conditions. Genetika, Vol. 49, pp. 891-910. https://doi.org/10.2298/GENSR1703891K

9. Lenaerts B., Collard B.C.Y., Demont M. 2019. Review: Improving global food security through accelerated plant breeding. Plant Science, Vol. 287, ID 110207. https://doi.org/10.1016/j.plantsci.2019.110207

10. Li G., Wang C., Feng M., Yang W., Li F., Feng R.,2017. Hyperspectral prediction of leaf area index of winter wheat in irrigated and rainfed fields. PLOS ONE, Vol. 12, e0183338. https://doi.org/10.1371/journal.pone.0183338

11. Niroula A., Khatri S., Timilsina R., Khadka D., Khadka A., Ojha P. 2019. Profile of chlorophylls and carotenoids of wheat (Triticum aestivum L.) and barley (Hordeum vulgare L.) microgreens. Journal of Food Science and Technology, Vol. 56, pp. $2758-2763$. https://doi.org/10.1007/s13197-019-03768-9

12. Pilipavičius V., Romaneckienė R., Romaneckas K. 2011. The effect of spring barley (Hordeum vulgare L.) sowing rate on the dynamics of crop weediness at different development stages. Zemdirbyste, Vol. 98, pp. 111-120.

13. Rezaei E.E., Siebert S., Hüging H., Ewert F. 2018. Climate change effect on wheat phenology depends on cultivar change. Scientific Reports, Vol. 8, pp. 1-10. https://doi.org/10.1038/s41598-018-23101-2

14. Sharifi P., Mohammadkhani N. 2016. Effects of Drought Stress on Photosynthesis Factors in Wheat Genotypes during Anthesis. Cereal Research Communications, Vol. 44, pp. 229-239. https://doi.org/10.1556/0806.43.2015.054

15. Skudra I., Ruza A. 2017. Effect of Nitrogen and Sulphur Fertilization on Chlorophyll Content in Winter Wheat. Jelgava Issn Rural Sustainability Research, Vol. 37. https://doi.org/10.1515/plua-2017-0004

16. Sugár E., Berzsenyi Z., Bónis P., Árendás T. 2017. Growth analysis of winter wheat cultivars as affected by nitrogen fertilization. Bodenkultur, Vol. 68, pp. 57-70. https://doi.org/10.1515/boku-2017-0005

17. Tian Y., Zheng C., Chen J., Chen C., Deng A., Song Z., Zhang B., Zhang W. 2014. Climatic Warming Increases Winter Wheat Yield but Reduces Grain Nitrogen Concentration in East China. PLOS ONE, Vol. 9, e95108. https://doi.org/10.1371/journal.pone.0095108

18. Von Wettstein D. 1957. Chlorophyll-letale und der submikroskopische Formwechsel der Plastiden. Experimental Cell Research, Vol. 12, pp. 427-506. https://doi.org/10.1016/0014-4827(57)90165-9

19. Vuletić M., Španić V. 2020. Special issue in honour of Prof. Reto J. Strasser - Characterization of photosynthetic performance during natural leaf senescence in winter wheat: Multivariate analysis as a tool for phenotypic characterization. Photosynthetica, Vol. 58, pp. 301-313. https://doi.org/10.32615/ps.2019.162

20. Wang L., Sun J., Wang C., Shangguan Z. 2018. Leaf photosynthetic function duration during yield formation of large-spike wheat in rainfed cropping systems. PeerJ 6, e5532. https://doi.org/10.7717/peerj.5532 